\title{
DIVERSITY OF MICROORGANISMS IN THE TRADITIONAL SLOVAK CHEESE
}

\author{
Miroslava Kačániová, Simona Kunová, Elena Horská, Ludmila Nagyová, Czeslaw Puchalski, \\ Peter Haščik, Margarita Terentjeva
}

\begin{abstract}
The aim of the present study was to describe the microbial groups of the traditional Slovak cheese Parenica during rippening. The microbial group included the total bacterial count, coliform bacteria, enterococci, lactic acid bacteria, and microscopic filamentous fungi, which may affect the organoleptic characteristics of this product. A total of 42 cheese samples were collected from four different farms during three months. The total bacterial counts were cultivated on Plate count agar at $30^{\circ} \mathrm{C}$, lactic acid bacteria (LAB) on MRS, APT and MSE at $37^{\circ} \mathrm{C}$, coliform bacteria on VRBL at $37^{\circ} \mathrm{C}$. Gram-positive and Gram-negative isolates were identified by MALDI-TOF MS profiling. Bacillus sp. and Enterococcus faecium were the most frequently identified species of bacteria. Candida kefyr was the most distributed yeast according to microbiological methods. Lactic acid bacteria group was represented by Lactobacillus helveticus, L. jensenii, $L$. alimentarius, L. crispatus, L. curvatus, L. fermentum, L. suebicus, L. delbrueckii ssp. lactis, L. paracasei ssp. paracasei, Lactococcus lactis ssp. lactis, Leuconostoc lactis and Le. mesenteroides ssp. mesenteroides. This report describing the indigenous microbiota of the traditional raw milk cheeses from Slovakia. Our results provide useful information on occurrence of valuable microbial strain for the industrialization of producing of the traditional dairy products in Slovakia.
\end{abstract}

Keywords: diversity; microbiota; smoked and non-smoked cheese; mass spectrometry

\section{INTRODUCTION}

Cheese is one of the oldest fermented foods (Oyetunji and Adebisi, 2018; Franke and Cwiková, 2019). The history of cheese lasts for thousands of years with changed related to the technical, social and economic conditions in different parts of the globe. Therefore the cheese fermentation process is attributed to culture and tradition (Štefániková et al., 2019). Especially cheese making traditions are pronounced in rural households and village communities. There are around 1000 types of (most artisanal) cheese known worldwide. Cheeses are very different in textures, aromas, visual presentations and flavours that is attributed to microbial activity. The microorganisms are present and growing in cheese-making process in large numbers and which degrade the components of the curd (Montel et al., 2014).

Diversity of sensory characteristics as flavor, smell, and texture of cheese are linked to microbiological activity in the product. Microorganisms show large metabolic capacities, and contribute the sensory parameters through the production of digestive enzymes and small molecules. Different cheese production technologies can lead to the growth of different microbial groups or microorganisms. The source and raw milk treatment (raw or pasteurized) used for cheesemaking can result in different microbiota of cheese. Changes in product characteristics during aging can significantly influence the cheese-associated microbiota with $\mathrm{pH}$, salt, moisture, and temperature of cheese reveal the biggest impact on microorganisms (Button and Dutton, 2012).

The microbiota of cheese rinds vary from simple to complex with Firmicutes, Actinobacteria, Proteobacteria, Bacteroidetes, yeasts and moulds are represented. The abundance and diversity of the microorganisms depend on cheese ripening process, type of rind (bloomy, washed or natural) and the processing technology (soft, hard or semihard). The lactic acid bacteria (LAB) from starter cultures are predominant in the initial stages of cheese ripening. Later, during ripening, the yeasts and/or moulds colonize the cheese surface and the yeast cell count may reach about $6-8 \log _{10} \mathrm{cfu}_{\mathrm{cm}} \mathrm{cm}^{-2}$. Those counts remains unchanged until the end of ripening. The growth of yeasts and/or moulds lead to lower $\mathrm{pH}$ of the cheese surface that favours the development of acid-sensitive, salt-tolerant bacteria. The final bacterial counts were $1-2 \log _{10}$ higher than that for yeast counts (Cogan et al., 2014).

From a technological point of view, the contamination of processed cheese by Gram-positive spore-forming rodshaped bacteria of the genera Bacillus, Geobacillus, and Clostridium is the most significant problem in cheesemaking. The shelf-life and microbiologicl quality of processed mostly are affected by the microbiological quality of the raw material, hygienic conditions during the manufacturing process, type of packaging materials and 
storage conditions. Other parameters such as the water activity, $\mathrm{pH}$, salts and emulsifying salts and fat in the product influence the overall quality of processed cheese as well (Buňková and Buňka, 2017).

The aim of our study was to detect the microbiota of the traditional Slovak cheese „Parenica“ and to identify the microorganisms by mass spectrometry.

\section{Scientific hypothesis}

Are there different bacteria and yeast species present in smoked and non-smoked traditional Slovak cheese?

Are microscopic filamentous fungi presented in traditional Slovak cheese?

\section{MATERIAL AND METHODOLOGY}

\section{Samples of cheese}

In our study, 42 samples of Slovak traditional cows cheese "Parenica" were examined during three moths. The cheese samples included non-smoked cheese $(n=21)$ and smoked cheese $(n=21)$. Additionally, 42 cow milk cheese samples from the western and middle Slovak producers were collected (Bánovce nad Bebravou, Liptovský Mikuláš, Červený Kameň, Važec). Samples were collected in sterilized sample containers and brought to laboratory in icebox for microbiological investigations. Samples were kept in a refrigerator $\left(4 \pm 1^{\circ} \mathrm{C}\right)$ until the testing began.

The primary dilution of cheese were made by adding of $5 \mathrm{~g}$ of sample to $45 \mathrm{~mL}$ of $0.87 \%$ sterile saline. Then, the serial dilutions $\left(10^{-2}\right.$ to $\left.10^{-4}\right)$ were done and $100 \mu \mathrm{L}$ of each dilution was plated out onto agars.

\section{Detection of total bacterial counts (TCB)}

Plate count agar (PCA, (Sigma-Aldrich ${ }^{\circledR}$, St. Louis, USA) for total count bacteria enumeration was used. Inoculated plates were incubated for $48-72 \mathrm{~h}$ at $30{ }^{\circ} \mathrm{C}$ and then examined for the presence of bacterial colonies.

\section{Isolation of coliform bacteria $(\mathrm{CB})$}

Violet red bile lactose agar (VRBGA, Sigma-Aldrich ${ }^{\circledR}$, St. Louis, USA) for enumeration of coliforms bacteria was used. Inoculated plates were incubated at $37{ }^{\circ} \mathrm{C}$ for $24-48 \mathrm{~h}$ and examined for the presence of typical colonies.

\section{Isolation of enterococci $(\mathbf{E})$}

Enterococcus selective agar (ESA, Sigma-Aldrich ${ }^{\circledR}$, St. Louis, USA) for enumeration of enterococci was used. Inoculated plates were incubated at $37{ }^{\circ} \mathrm{C}$ for $24-48 \mathrm{~h}$ and examined for the presence of typical colonies.

\section{Isolation of lactic acid bacteria (LAB)}

MRS (Main Rogose agar), MSE (Mayeux, Sandine and Elliker) and APT (All Purpose TWEEN® agar, SigmaAldrich ${ }^{\circ}$, St. Louis, USA) agars were used for cultivation of lactic acid bacteria. Inoculated plates were incubated at $37{ }^{\circ} \mathrm{C}$ for $72 \mathrm{~h}$ anaerobically and then the bacterial growth was evaluated.

\section{Isolation of microscopic fungi and yeasts (MFY)}

Malt extract agar (Sigma-Aldrich ${ }^{\circledR}$, St. Louis, USA) and acid base indicator bromocresol green (Sigma-Aldrich ${ }^{\circledR}$,
St. Louis, USA) (0.020 g. . $\left.^{-1}\right)$ were used for microscopic fungi and yeasts identification. Inoculated plates were incubated at $25{ }^{\circ} \mathrm{C}$ for 5 days aerobically and then the growth was evaluated.

The colonies from total bacterial counts, Enterobacteriales, enterococci and lactic acid bacteria were selected for further confirmation with MALDI-TOF. Selected colonies were cultured overnight on TSA agar (Tryptone Soya Agar) aerobically or anaerobically and used for identification.

\section{Sample preparation and MALDI-TOF MS measurement}

One colony of each bacterial isolate was transferred into an Eppendorf tubes and mixed with $300 \mu \mathrm{L}$ of sterile water. After addition of ethanol $(900 \mu \mathrm{L})$, the suspension was mixed and centrifuged $(13,000 \mathrm{~g}, 2 \mathrm{~min})$. After removal of supernatant, the pellets were dried at room temperature at least for $5 \mathrm{~min}$. The bacterial pellets were resuspended in $20-50 \mu \mathrm{L}$ of formic acid $(70 \%)$ and the same amount of acetonitrile. After centrifugation (2 min at $13,000 \mathrm{~g}$ ), a $1 \mu \mathrm{L}$ of supernatant was spotted onto a sample position of a polished steel MALDI target plate and dried at room temperature. A $1 \mu \mathrm{L}$ of MALDI matrix (solution of $\alpha$-cyano-4-hydroxycinnamic acid (HCCA) in $50 \%$ acetonitrile $/ 2.5 \%$ trifluoro-acetic acid) was added to the spot and dried.

The MALDI target plate was introduced into the MALDI-TOF mass spectrometer for automated measurement and data interpretation. MALDI-TOF profile mass spectra were imported into the MALDI Biotyper 3.0 software and processed automatically after measurement. The logarithm of the score $(\log [\mathrm{score}])$ was displayed as the matching result. The MALDI Biotyper output was a $\log$ (score) between 0 and 3.0, which was calculated from a comparison of the peak list from an unknown isolate with the reference MSP in the database. A $\log$ (score) $\geq 1.7$ indicated identification at the genus level, $\log ($ score $) \geq 2.0$ was set as the threshold for a match at the species level. Isolates with $\geq 2.0$ were accepted as a correct identification.

\section{Statistic analysis}

All experiments were carried out in triplicate. Standard deviations were calculated for replications. The experimental data were subjected to analysis of variance (Duncan's test) at the $95 \%$ confidence level of 0.05 (software XL STAT, 2019).

\section{RESULTS AND DISCUSSION}

The results on non-smoked and smoked cheese bacterial counts, including coliform bacteria, enterococci, total bacterial count, lactic acid bacteria and microscopic filamentous fungi are shown in Table 1. Coliforms bacteria were not found in samples with exception of sample no.6, where coliform bacteria counts ranged from 3.17 to $3.43 \mathrm{log}$ CFU.g ${ }^{-1}$. Number of enterococci ranged from 2.09 till $4.32 \log$ CFU.g ${ }^{-1}$. Total count of bacteria in cheese samples ranged from 3.17 till 4.36 log CFU.g $^{-1}$. Microscopic filamentous fungi ranged from 2.26 till $3.38 \log$ CFU.g ${ }^{-1}$. How we can see in our results the worst results were found in sample number 6 . The composition of the cheese surface microbiota has been studied for 
several decades via the application of conventional, culture-based analyses (Valdés-Stauber, Scherer and Seiler, 1997; Maoz, Mayr and Scherer, 2003; Viljoen, Khoury and Hattingh, 2003; Feurer et al., 2004; Mounier et al., 2005, Mounier et al., 2009; Callon et al., 2006; Florez and Mayo, 2006; Larpin et al., 2006; Lopandic et al., 2006; Rea et al., 2007; Goerges et al., 2008; Bleicher et al., 2010; Roth et al., 2010; LarpinLaborde et al., 2011; Amato et al., 2012; Lavoie et al., 2012; Panelli et al., 2012; Gori et al., 2013; Cogan et al., 2014; Gkatzionis et al., 2014).

From the genus Acinetobacter 4 different strains were isolated: A. baumannii, A. dijkshoorniae, A. johnsonii and A. junii. Acinetobacter were found in $33.33 \%$ of samples (Table 2). Candida was also widelt distributed and C. kefyr, C. parapsilosis, C. rugosa, C. guilliermondii, candida zeylanoides and $C$. lusitaniae were isolated. From Enterobacteriaceae Enterobacter cloacea, Hafnia alvei, Citrobacter braakii, C. freundii, Klebsiella oxytoca and Serratia ureilytica were found. The most abundant genus was Enterococcus with three species were detected: E. durans, E. faecium and E. faecalis. Among yeasts Kluyveromyces, Saccharomyces and Yarrowia were identified.

Secondary microflora such as yeasts could be frequently isolated from different types of cheeses with counts from $10^{4}-10^{6} \mathrm{cfu} . \mathrm{g}^{-1}$ to $10^{7}-10^{8} \mathrm{cfu}^{-\mathrm{g}^{-1}}$. The presence of yeasts in cheese could be attributed to the favourable conditions for their growth and the wide distribution in dairy environment (Wyder, 2003; Alessandria et al., 2010; Mirzaei, 2011). The role of the presence of yeast depends on the particular type of cheese (Wyder, 2003; Colombo, Borgo and Fortina, 2009). Yeasts are important for bacterial development in cheese but their influence on bacteria may vary (Mounier et al., 2009). Yeasts can cause sensory defects as excessive gas production and cheese blowing, bitter taste, fruit flavours, changes in acidity and texture profile (Wyder, 2003). Nevertheless, the yeasts can alter the unique characteristics of several cheeses due to their lipolytic and proteolytic activities, formation of aromatic compounds, and degradation of the lactic acid (Wyder, 2003; De Freitas et al., 2009).

Among lactic acid bacteria the following species were isolated: Lactobacillus helveticus, L. jensenii, L. alimentarius, L. crispatus, L. curvatus, L. fermentum, L. suebicus, L. delbrueckii ssp. lactis, L. paracasei ssp. paracasei Lactococcus lactis ssp. lactis, Leuconostoc lactis and Leu. mesenteroides subsp. mesenteroides (Table 2).

Lactic acid bacteria are the most studied microorganisms in milk fermentation (Olson, 1990; Urbach, 1995; Maragkoudakis et al., 2006). The LAB in milk fermentation can be either as contaminants or content starter cultures. Milk itself serve as one of the natural source of LAB (Delavenne et al., 2012; Wouters et al., 2002). Under spontaneous fermentations, the growth of LAB can not be controlled, but this procedure has been done during traditional cheese production. Backslopping also is often used in traditional cheese production and under this procedure fermented milk products as artisanal cheese klila (Mennane et al., 2007), kumis (ChavesLópez et al., 2011), iben (Ouadghiri et al., 2008) and kurut (Sun et al., 2010) are produced. In general, the technology of milk fermentation is relatively simple and cost-effective. The large-scale production of standardized fermented milk products in controlled conditions require the industrial application of LAB as starter cultures. There are significant differences in the composition of industrally produced cheese with additional of starter culture from naturally fermented product with high microbial diversity in the traditional, naturally fermented products (Widyastuti, Rohmatussolihat and Febrisiantosa, 2014).

Among staphylococci Staphylococcus warneri, S. epidermidis, S. saprophyticus subsp. saprophyticus, S. sciuri subsp. carnaticus, S. cohnii, S. xylosus and S. hominis were isolated.

Three Staphylococcus species were isolated previously with distribution of certain species in particular cheese: $S$. equorum was unique to ardrahan and milleens cheeses, $S$. saprophyticus to gubbeen cheese, and S. epidermidis to durrus cheese. S. equorum and $S$. saprophyticus have been

Table 1 Microbial counts in traditional Slovak cheese.

\begin{tabular}{|c|c|c|c|c|c|}
\hline & CB & $\mathbf{E}$ & TCB & LAB & MFY \\
\hline Non- smoked cheese 1 & $0.00 \pm 0.00$ & $2.46 \pm 0.05^{\mathrm{def}}$ & $3.67 \pm 0.06^{\text {cde }}$ & $3.77 \pm 0.16^{\mathrm{a}}$ & $2.72 \pm 0.14^{\mathrm{bc}}$ \\
\hline Smoked cheese 1 & $0.00 \pm 0.00$ & $2.29 \pm 0.07^{\mathrm{fgh}}$ & $3.54 \pm 0.09^{\mathrm{ef}}$ & $3.47 \pm 0.20^{\text {bcde }}$ & $2.30 \pm 0.13^{\mathrm{ef}}$ \\
\hline Non- smoked cheese 2 & $0.00 \pm 0.00$ & $2.60 \pm 0.07^{\mathrm{d}}$ & $3.62 \pm 0.09^{\mathrm{de}}$ & $3.87 \pm 0.09^{\mathrm{a}}$ & $2.79 \pm 0.05^{\mathrm{b}}$ \\
\hline Smoked cheese 2 & $0.00 \pm 0.00$ & $2.23 \pm 0.02^{\mathrm{hi}}$ & $3.17 \pm 0.05^{\mathrm{h}}$ & $3.52 \pm 0.06^{\mathrm{bcd}}$ & $2.46 \pm 0.14^{\text {cde }}$ \\
\hline Non- smoked cheese 3 & $0.00 \pm 0.00$ & $2.41 \pm 0.15^{\mathrm{efg}}$ & $3.74 \pm 0.15^{\mathrm{cd}}$ & $3.64 \pm 0.10^{\mathrm{abc}}$ & $2.52 \pm 0.07^{\mathrm{cd}}$ \\
\hline Smoked cheese 3 & $0.00 \pm 0.00$ & $2.17 \pm 0.02^{\mathrm{hi}}$ & $3.24 \pm 0.04^{\mathrm{gh}}$ & $3.46 \pm 0.19^{\text {bcde }}$ & $2.26 \pm 0.05^{\mathrm{f}}$ \\
\hline Non- smoked cheese 4 & $0.00 \pm 0.00$ & $2.55 \pm 0.02^{\mathrm{de}}$ & $3.70 \pm 0.14^{\text {cde }}$ & $3.70 \pm 0.17^{\mathrm{ab}}$ & $2.75 \pm 0.10^{\mathrm{b}}$ \\
\hline Smoked cheese 4 & $0.00 \pm 0.00$ & $2.32 \pm 0.11^{\mathrm{fgh}}$ & $3.34 \pm 0.08^{\mathrm{gh}}$ & $3.40 \pm 0.17^{\text {cdef }}$ & $2.43 \pm 0.09^{\mathrm{def}}$ \\
\hline Non- smoked cheese 5 & $0.00 \pm 0.00$ & $2.44 \pm 0.11^{\mathrm{defg}}$ & $3.88 \pm 0.09^{c}$ & $3.51 \pm 0.19^{\mathrm{bcd}}$ & $2.72 \pm 0.17^{b}$ \\
\hline Smoked cheese 5 & $0.00 \pm 0.00$ & $2.09 \pm 0.04^{\mathrm{i}}$ & $3.41 \pm 0.13^{\mathrm{fg}}$ & $3.23 \pm 0.09^{\mathrm{ef}}$ & $2.38 \pm 0.15^{\mathrm{def}}$ \\
\hline Non- smoked cheese 6 & $3.17 \pm 0.03^{b}$ & $4.32 \pm 0.23^{\mathrm{a}}$ & $4.36 \pm 0.14^{\mathrm{a}}$ & $3.37 \pm 0.09^{\mathrm{def}}$ & $3.38 \pm 0.12^{\mathrm{a}}$ \\
\hline Smoked cheese 6 & $3.43 \pm 0.10^{\mathrm{a}}$ & $3.53 \pm 0.06^{\mathrm{b}}$ & $4.08 \pm 0.03^{\mathrm{b}}$ & $3.19 \pm 0.07^{\mathrm{f}}$ & $3.28 \pm 0.06^{\mathrm{a}}$ \\
\hline Non- smoked cheese 7 & $0.00 \pm 0.00$ & $2.84 \pm 0.09^{c}$ & $3.60 \pm 0.07^{\mathrm{de}}$ & $3.68 \pm 0.10^{\mathrm{ab}}$ & $2.75 \pm 0.09^{b}$ \\
\hline Smoked cheese 7 & $0.00 \pm 0.00$ & $2.27 \pm 0.06^{\mathrm{gh}}$ & $3.27 \pm 0.03^{\mathrm{gh}}$ & $3.50 \pm 0.14^{\mathrm{bcd}}$ & $2.37 \pm 0.05^{\mathrm{def}}$ \\
\hline
\end{tabular}

Note: mean \pm standard deviation; different letters in column mean that the differences were significant. 
Table 2 Microorganisms isolated from non-smoked and smoked cheese "Parenica".

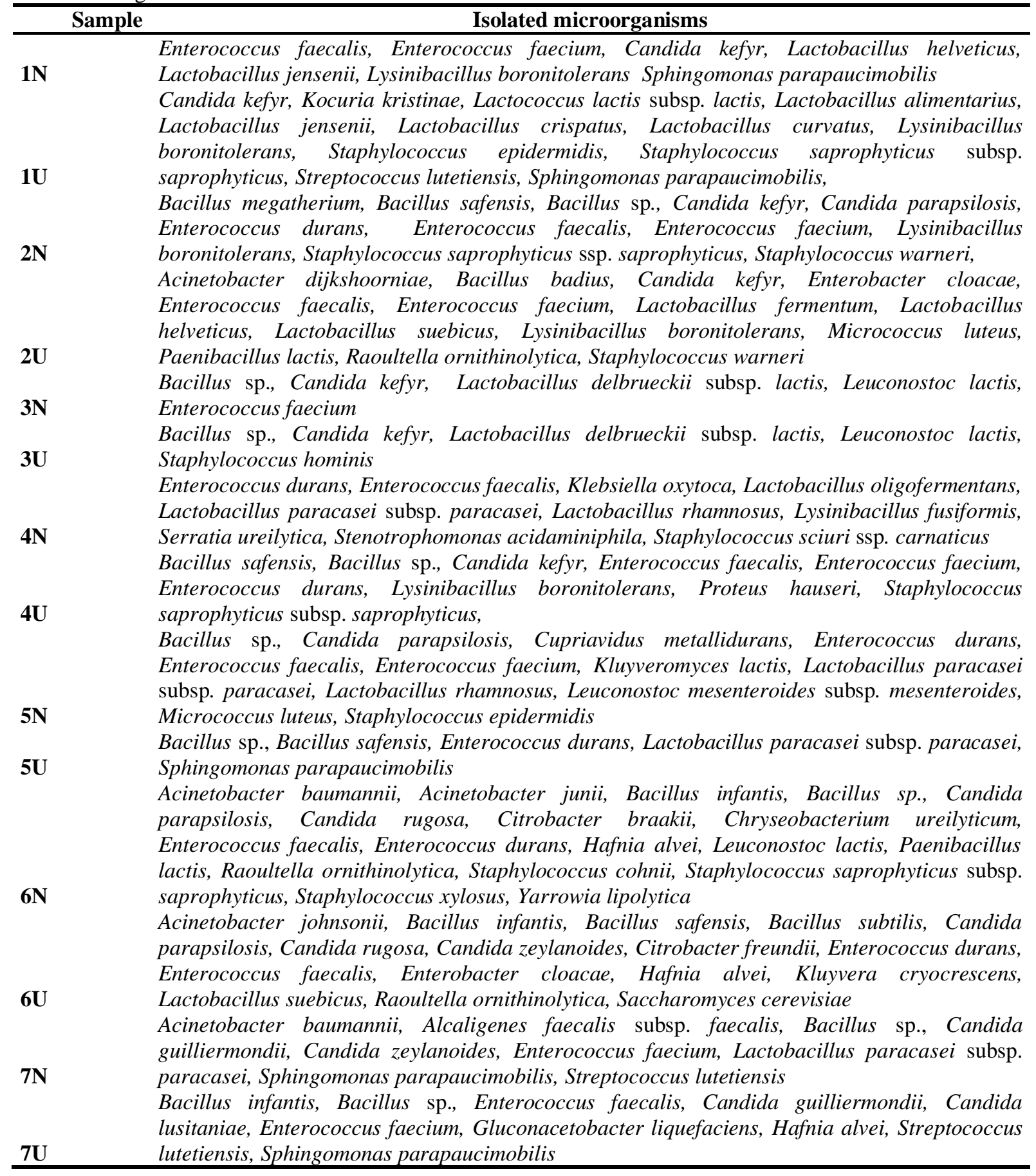

isolated previously from the surfaces of traditional French cheeses (Irlinger et al., 1997).

Bacillus megatherium, Bacillus sp., B. infantis, B. safensis, B. subtilis, B. badius were representatives of the genus Bacillus.

\section{CONCLUSION}

This study was designed to evaluate coliform bacteria, enterococci, yeasts and LAB population's in Slovak traditional non-smoked and smoked cheese. Our results show that the traditional Slovak cheese contains very diverse microbiota. In our study, the mass spectrometry method allowed the accurate identification of microorganisms and this method was reliable and easy done for identification in comparison with molecular methods.

\section{REFERENCES}

Alessandria, V., Dolci, P., Rantsiou, K., Pattono, D., Dalmasso, A., Civera, T., Cocolin, L. 2010. Microbiota of the Planalto de Bolona: an artisanal cheese produced in uncommon environmental conditions in the Cape Verde Islands. World Journal of Microbiology and Biotechnology, vol. 26, no. 12, p. 2211-2221. https://doi.org/10.1007/s11274010-0406-7

Amato, L., Ritschard, J. S., Kurtz, O. Arias-Roth, E., Lacroix, C., Schuppler, M., Meile, L. 2012. Microbial composition of defect smear-a problem evolving during foilprepacked storage of red-smear cheeses. International Dairy Journal, vol. 27, no. 1-2, p. 77-85. https://doi.org/10.1016/j.idairyj.2012.07.012

Bleicher, A., Obermajer, T., Matijasic, B. B., Siegfried Scherer, S., Neuhaus, K. 2010. High biodiversity and potent 
anti-listerial action of complex red smear cheese microbial ripening consortia. Annals of Microbiology, vol. 60, no. 3, p. 531-539. https://doi.org/10.1007/s13213-010-0083-7

Buňková, L., Buňka, F. 2017. Microflora of processed cheese and the factors affecting it. Critical Reviews in Food sciences and Nutrition, vol. 57, no. 11, p. 2392-2403. https://doi.org/10.1080/10408398.2015.1060939

Button, J. E., Dutton, R. J. 2012. Cheese microbes. Current Biology, vol. 22, no. 15, p. 587-589. https://doi.org/10.1016/j.cub.2012.06.014

Callon, C., Delbes, C., Duthoit, F., Montel, C. M. 2006. Application of SSCP-PCR fingerprinting to profile the yeast community in raw milk Salers cheese. Systematic and Applied Microbiology, vol. 29, no. 2, p. 172-180. https://doi.org/10.1016/j.syapm.2005.07.008

Cogan, T. M., Goerges, S., Gelsomino, R., Donnelly, C. W. 2014. Biodiversity of the surface microbial consortia from Limburger, Reblochon, Livarot, Tilsit, and Gubbeen cheeses. Microbiology Spectrum, vol. 2, no.1. https://doi.org/10.1128/microbiolspec.CM-0010-2012

Colombo, F., Borgo, F., Fortina M. G. 2009. Genotypic characterization of non starter lactic acid bacteria involved in the ripening of artisanal Bitto PDO cheese. Journal of Basic Microbiology, vol. 49, no. 6, p. 521-530. https://doi.org/10.1002/jobm.200800381

De Freitas, I., Pinon, N., Maubois, J. L., Lortal, S., Thierry A. 2009. The addition of a cocktail of yeast species to Cantalet cheese changes bacterial survival and enhances aroma compound formation. International Journal of Food Microbiology, vol. 129, no. 6, 37-42. https://doi.org/10.1016/j.ijfoodmicro.2008.10.026

Delavenne, E., Mounier, J. Déniel, F. Barbier, G., Le Blay, G. 2012. Biodiversity of antifungal lactic acid bacteria isolated from raw milk samples from cow, ewe and goat over one-year period. International Journal of Food Microbiology, vol. 155, no. 3, p. 185-190. https://doi.org/10.1016/j.ijfoodmicro.2012.02.003

Feurer, C., Irlinger, F., Spinnler, H., Spinnler, E., Glaser, P., Vallaeys, T. 2004. Assessment of the surface microbial diversity in a farm house-produced vs a pasteurized industrially produced soft red-smear cheese using both cultivation and rDNA-based methods. Journal of Applied Microbiology, vol. 97, no. 3, p. 546-556. https://doi.org/10.1111/j.1365-2672.2004.02333.x

Florez, A. B., Mayo, B. 2006. Microbial diversity and succession during the manufacture and ripening of traditional, Spanish, blue-veined Cabrales cheese, as determined by PCRDGGE. International Journal of Food Microbiology, vol. 110, no. $2, \quad$ p. $165-171$. https://doi.org/10.1016/j.ijfoodmicro.2006.04.016

Franke, G., Cwiková, O. 2019. Biogenic amines in smear ripened cheeses. Potravinarstvo Slovak Journal of Food Sciences, vol. 13, no. 1, p. 378-384. https://doi.org/10.5219/1105

Gkatzionis, K., Yunita, D., Linforth, R. S. T., Dickinson, M., Dodd, C. E. R. 2014. Diversity and activities of yeasts from different parts of a Stilton cheese. International Journal of Food Microbiology, vol. 177, p. 109-116. https://doi.org/10.1016/j.ijfoodmicro.2014.02.016

Goerges, S., Mounier, J., Rea, M., Gelsomino, C., Heise, V., Beduhn, R., Cogan, T. M., Vancanneyt, M., Scherer, S. 2008. Commercial ripening starter microorganisms inoculated into cheese milk do not successfully establish themselves in the resident microbial ripening consortia of a South German red smear cheese. Applied Environmental Microbiology, vol. 74, no. 7, p. 2210-2217. https://doi.org/10.1128/AEM.01663-07
Gori, K., Ryssel, M., Arneborg, N., Jespersen, L. 2013. Isolation and identification of the microbiota of Danish farmhouse and industrially produced surface-ripened cheeses Microbial Ecology, vol 65, no. 3, p. 602-615. https://doi.org/10.1007/s00248-012-0138-3

Chaves-López, C., Serio, A., Martuscelli, M., Paparella, A., Osorio-Cadavid, E., Suzzi, G. 2011. Microbiological characteristics of kumis, a traditional fermented colombian milk, with particular emphasis on enterococci population," Food Microbiology, vol. 28, no. 5, p. 1041-1047. https://doi.org/10.1016/j.fm.2011.02.006

Irlinger, F., Morvan, A., El Solh, A. N., Bergere, J. L. 1997. Taxonomic characterisation of coagulase-negative staphylococci in ripening flora from traditional French cheeses. Systematic and Applied Microbiology, vol. 20, no. 2, p. 319-328. https://doi.org/10.1016/S0723-2020(97)80079-3

Larpin, S., Mondoloni, C., Goerges, S., Vernoux, J. P., Guguen, M., Desmasures, N. 2006. Geotrichum candidum dominates in yeast population dynamics in Livarot, a French red-smear cheese. FEMS Yeast Research, vol. 6, no. 8, p. 1243-1253. https://doi.org/10.1111/j.1567-1364.2006.00127.x

Larpin-Laborde, S., Imran, M., Bonaïti, C., Bora, N., Gelsomino, R., Goerges, S., Irlinger, F., Goodfellow, M., Ward, A. C., Vancanneyt, M., Swings, J., Scherer, S., Guéguen, S., Desmasures, N. 2011. Surface microbial consortia from Livarot, a French smear ripened cheese. Canadian Journal of Microbiology, vol. 57, no. 8, p. 651-660. https://doi.org/10.1139/w11-050

Lavoie, K., Touchette, M., St-Gelais, D., Labrie, S. 2012. Characterization of the fungal microflora in raw milk and specialty cheeses of the province of Quebec. Dairy Science and Technology, vol. 92, no. 5, p. 455-468. https://doi.org/10.1007/s13594-011-0051-4

Lopandic, K., Zelger, S., Banszky, L. K., EliskasesLechner, F., Prillinger, H. 2006. Identification of yeasts associated with milk products using traditional and molecular techniques. Food Microbiology, vol. 23, no. 4, p. 341-350. https://doi.org/10.1016/j.fm.2005.05.001

Maoz, A., Mayr, R., Scherer, S. 2003. Temporal stability and biodiversity of two complex antilisterial cheese-ripening microbial consortia. Applied and Environmental Microbiology, vol. 69, no. 7, p. 4012-4018. https://doi.org/10.1128/AEM.69.7.4012-4018.2003

Maragkoudakis, P. A., Miaris, C., Rojez, P., Manalis, N. Magkanari, F., Kalantzopoulos, G., Tsakalidou, E. 2006. Production of traditional Greek yoghurt using Lactobacillus strains with probiotic potential as starter adjuncts. International Dairy Journal, vol. 16, no. 1, p. 52-60. https://doi.org/10.1016/j.idairyj.2004.12.013

Mennane, Z., Khedid, K., Zinedine, A., Lagzouli, M., Ouhssine, M., Elyachioui, M. 2007. Microbial characteristics of klila and jben traditional Moroccan cheese from waw cow's milk. World Journal of Dairy and Food Sciences, vol. 2, no. 1, p. 23-27.

Mirzaei, H. 2011. Microbiological changes in Lighvan cheese throughout its manufacture and ripening. African Journal of Microbiology Research, vol. 5, no. 13, 1609-1614. https://doi.org/10.5897/AJMR11.111

Montel, M. C., Buchin, S., Mallet, A., Delbes-Paus, C., Vuitton, D. A., Desmasures, N., Berthier, F. 2014. Traditional cheeses: rich and diverse microbiota with associated benefits. International Journal of Food Microbiology, vol. 177, p. 136154. https://doi.org/10.1016/j.ijfoodmicro.2014.02.019

Mounier, J. Monnet, C., Jacques, N., Antoinette, A., Irlinger, F. 2009. Assessment of the microbial diversity at the surface of Livarot cheese using culture-dependent and 
independent approaches. International Journal of Food Microbiology, vol. 133, no. 1-2, p. 31-37. https://doi.org/10.1016/j.ijfoodmicro.2009.04.020

Mounier, J., Gelsomino, R., Goerges, S., Vancanneyt, M., Vandemeulebroecke, K., Hoste, B., Scherer, S., Swings, J., Fitzgerald, J. F., Cogan, T. M. 2005. Surface microflora of four smear-ripened cheeses. Applied and Environmental Microbiology, vol. 71, p. 6489-6500. https://doi.org/10.1128/AEM.71.11.6489-6500.2005

Olson, N. F. 1990. The impact of lactic acid bacteria on fheese Flavor. FEMS Microbiology Reviews, vol. 87, no. 1-2, p.131-148. https://doi.org/10.1016/0378-1097(90)90702-R

Ouadghiri, M., Vancanneyt, M., Vandamme, P., Naser, S., Gevers, D., Lefebvre, K., Swings, J., Amar, M. 2008. Identification of lactic acid bacteria in Moroccan raw milk and traditionally fermented skimmed milk 'Lben'. Journal of Applied Microbiology, vol. 106, no. 2, p. 486-495. https://doi.org/10.1111/j.1365-2672.2008.04016.x

Oyetunji, O. A., Adebisi, K. A. 2018. Assessment of the functional quality and safety of yoghurts produced with starter cultures obtained from selected commercially sold yoghurts. Potravinarstvo Slovak Journal of Food Sciences, vol. 12, no. 1, p. 587-599. https://doi.org/10.5219/952

Panelli, S., Buffoni, J. N., Bonacina, C., Feligini, B. 2012. Identification of moulds from the Taleggio cheese environment by the use of DNA barcodes. Food Control, vol. 28, no. $2, \quad$ p. 385-391. https://doi.org/10.1016/j.foodcont.2012.05.022

Rea, M. C., Goerges, S., Gelsomino, R., Brennan, M. Mounier, J. Vancanneyt, M. Scherer, S. Swings, J., Cogan, T.M. 2007. Stability of the biodiversity of the surface consortia of Gubbeen, a red-smear cheese. Journal of Dairy Sciences, vol. 90, no. 5, p. 2200-2210. https://doi.org/10.3168/jds.2006-377

Roth, E., Schwenninger, S. M., Hasler, M., Eugster-Meier, E., Lacroix, C. 2010. Population dynamics of two antilisterial cheese surface consortia revealed by temporal temperature gradient gel electrophoresis. BMC Microbiology, vol. 10, no. 1, p. 74-87. https://doi.org/10.1186/1471-2180-10-74

Sun, Z., Liu, W., Gao, W., Yang, M., Zhang, J., Wu, L., Wang, J., Menghe, B., Sun T., Zhang, H. 2010. Identification and characterization of the dominant lactic acid bacteria from Kurut: the naturally fermented yak milk in Qinghai, China. Journal of General and Appllied Microbiology, vol. 56, no. 1, p. 1-10. https://doi.org/10.2323/jgam.56.1

Štefániková, J., Nagyová, V., Hynšt, M., Vietoris, V., Martišová, P., Nagyová, L. 2019. Application of electronic nose for determination of Slovak cheese authentication based on aroma profile. Potravinarstvo Slovak Journal of Food Sciences, vol. 13, no. 1, p. 262-267. https://doi.org/10.5219/1076

Urbach, G. 1995. Contribution of lactic acid bacteria to flavour compound formation in dairy products. International Dairy Journal, vol. 5, no. 8, p. 877-903. https://doi.org/10.1016/0958-6946(95)00037-2

Valdés-Stauber, N., Scherer, S., Seiler, H. 1997. Identification of yeasts and coryneform bacteria from the surface microflora of brick cheeses. International Journal of Food Microbiology, vol. 34, no. 2, p. 115-129. https://doi.org/10.1016/S0168-1605(96)01171-3

Viljoen, B. C., Khoury, A. R., Hattingh, A. 2003. Seasonal diversity of yeasts associated with white-surface mouldripened cheeses. Food Research International, vol. 36, no. 2, p. 275-283. https://doi.org/10.1016/S0963-9969(02)00169-2
Widyastuti, Y., Rohmatussolihat, Febrisiantosa, A. 2014. The role of lactic acid bacteria in milk fermentation. Food and Nutrition Sciences, vol. 5, no. 4, p. 248-278.

Wouters, J. T. M., Ayad, E. H. E., Hugenholtz, J., Smit, G. 2002. Microbes from raw milk for fermented dairy products. International Dairy Journal, vol. 12, no. 2-3, p. 91-109. https://doi.org/10.1016/S0958-6946(01)00151-0

Wyder, M. T. 2003. Yeasts in dairy products. Woodhead Publishing Series in Food Science, Technology and Nutrition, p. 209-237. https://doi.org/10.1533/97 $\underline{81845698485.209}$

\section{Acknowledgments:}

This work has been supported by the grant APVV-16-0244 "Qualitative factors affecting the production and consumption of milk and cheese".

\section{Contact address:}

*Miroslava Kačániová, Slovak University of Agriculture, Faculty of Biotechnology and Food Sciences, Department of Microbiology, Tr. A. Hlinku 2, 949 76, Nitra Slovakia, Faculty of Biology and Agriculture, University of Rzeszow, Department of Bioenergy Technology and Food Analysis, Zelwerowicza St. 4, 35-601 Rzeszow, Poland, Tel.: +421376414494,

E-mail: miroslava.kacaniova@gmail.com

ORCID: https://orcid.org/0000-0002-4460-0222

Simona Kunová, Slovak University of Agriculture, Faculty of Biotechnology and Food Sciences, Department of Food Hygiene and Safety, Tr. A. Hlinku 2, 94976 Nitra, Slovakia, Tel.: +421376415807,

E-mail: simona.kunova@ uniag.sk

ORCID: https://orcid.org/0000-0003-2240-1756

Elena Horská, Slovak University of Agriculture in Nitra, Faculty of Economics and Management, Department of Marketing and Trade, Tr. A. Hlinku 2, 94976 Nitra, Slovakia, Tel.: +421376415179,

E-mail: elena.horska@uniag.sk

ORCID: https://orcid.org/0000-0002-4973-9573

Ludmila Nagyová, Slovak University of Agriculture in Nitra, Faculty of Economics and Management, Department of Marketing and Trade, Tr. A. Hlinku 2, 94976 Nitra, Slovakia, Tel.: +421376414102,

E-mail: ludmila.nagyova@uniag.sk

ORCID: https://orcid.org/0000-0002-5220-2857

Czeslaw Puchalski, Faculty of Biology and Agriculture, University of Rzeszow, Department of Bioenergy Technology and Food Analysis, Zelwerowicza St. 4, 35601 Rzeszow, Poland, Tel.: +48178721000,

E-mail: cpuchal@univ.rzeszow.pl

Peter Haščík, Slovak University of Agriculture, Faculty of Biotechnology and Food Sciences, Department of Evaluation and Processing of Animal Products, Tr. A. Hlinku 2, 94976 Nitra, Slovakia, Tel.: +421376414708,

E-mail: peter.hascik@uniag.sk

ORCID: https://orcid.org/0000-0002-3402-5658

Margarita Terentjeva, Latvia University of Life Sciences and Technologies, Faculty of Veterinary Medicine, Institute of Food and Environmental Hygiene, K. Helmaņa iela 8, LV-3004, Jelgava, Latvia, Tel.: +37163027666,

E-mail: margarita.terentjeva@1lu.lv

ORCID: https://orcid.org/0000-0002-6306-8374 